\title{
Assessing the Role of Agroforestry in Soil Fertility Improvement in Mbelenka-Lebialem, Southwest Cameroon
}

\author{
Azembouh Roshinus Tsufac \\ Department of Forestry, Faculty of Agronomy and Agricultural Sciences (FASA), \\ University of Dschang, Dschang, Cameroon \\ E-mail: azembouh1990@gmail.com / azembouh1990@yahoo.com
}

\begin{abstract}
Bernard Palmer Kfuban Yerima
Department of Soil Science, Faculty of Agronomy and Agricultural Sciences (FASA), University of Dschang, Dschang, Cameroon

E-mail: bernardyerima@yahoo.com

Nyong Princely Awazi (Corresponding author)

Department of Forestry, Faculty of Agronomy and Agricultural Sciences (FASA), University of Dschang, Dschang, Cameroon

E-mail: nyongprincely@gmail.com
\end{abstract}

Received: October 28, 2019 Accepted: December 2, 2019 Published: December 5, 2019

doi:10.5296/ijgs.v3i1.15729 URL: https://doi.org/10.5296/ijgs.v3i1.15729

\begin{abstract}
Soils are the universal reservoirs through which living organisms get the resources for their livelihoods either directly like plants and indirectly like other organisms and animals. The ability of soils to serve as a universal reservoir depends on its fertility. Agroforestry practices have been seen to improve and conserve soil fertility. This research work carried out from the $10^{\text {th }}$ of May 2015 to the $10^{\text {th }}$ of November 2015 was aimed at assessing the role of
\end{abstract}


agroforestry practices in the improvement of soil fertility in the study area. Information was collected using questionnaires, field surveys and the analysis of soil samples in the laboratory. The results obtained were subjected to regression and correlation analysis using the Statistical Package for Social Sciences (SPSS). These results showed that the main agroforestry practices in this area include live fences and scattered trees on farmlands. It was also observed that farmers use indicators such as yields, softening of soil, wilting of the crops, rotten tubers, erosion and rains to determine soil fertility. There was no significant difference between various soil parameters ( $\mathrm{pH}$, acidity, CEC, ECEC, C/N, and exchangeable Al) in the two major agroforestry practices identified. There was equally no significant difference between the various soil elements and yields in the two major systems identified. The only element that showed a significant difference $(\mathrm{P}<5 \%)$ in the two systems and also for yields was phosphorous. Since only phosphorous significantly influenced yields in this area, a model was established to show that crop yields are dependent on phosphorous as indicated by the equation Yields $=1.77+0.03 \mathrm{P}$. Scattered trees on farm lands were recommended to farmers, the practice of improved fallow using a local fertilizing species identified as well as the use of Guatemala grass (Tripsacum laxum) and Vetiver grass (Vetiveria zizanoides) should be introduced on slopes to control erosion.

Keywords: Soil fertility, Adaptation options, Agroforestry practices, Agroforestry systems, South-west Cameroon

\section{Introduction}

Soil fertility degradation on smallholder farms has been cited as the fundamental biophysical cause of food insecurity and poverty in sub-Saharan Africa (SSA), where most of the people live in rural areas and derive their livelihoods from agriculture (Sanchez et al., 1981). In Africa, poor soil management and the fragile nature of soils generally account for heavy nutrient losses through soil erosion and nutrient leaching in soils (Hossner \& Juo, 1999). Unsuitable soil management activities including deforestation, indiscriminate vegetation removal, overgrazing and use of marginal lands for agricultural purposes often precedes eventual degradation of soil resources and environmental damage in Africa (Henao \& Baanante, 2006). Also farmers are either entirely abandoning the traditional practices of using natural fallow to restore soil fertility or are unable to leave land fallow long enough for it to gain its fertility as a result of the rise in human population which has led to increases in demand for land use even by other sectors of the economy other than the agricultural sector (Agyarko et al., 2011).

The major problems of soil productivity in Sub-Saharan African (SSA) countries include population growth, pressure on land, food production practices, land degradation and soil fertility decline, drought, land rights and technology (Melane et al., 2008; Awazi \& Tchamba, 2019). Chemical fertilizers could be part of the solutions to correct soil degradation and properly address rising food demands but the average fertilizer use in Africa is very low and ineffective for sustaining crop and soil fertility maintenance (about $8 \mathrm{~kg} / \mathrm{ha}$, i.e; only $1 / 10^{\text {th }}$ of the World average) (Gruhn et al., 2000; Marco et al., 2006). Excess fertilizer use also contributes to a suite of negative environmental outcomes including climate change, eutrophication, tropospheric ozone depletion, and loss in biodiversity and species extinctions (Erisman et al., 2011). 
Soil nutrient depletion and likely degradation have been considered serious threats to agricultural productivity and have been identified as major causes of decreased crop yields and per capital food production in Sub-Saharan African countries (Henao \& Baanante, 2006; Awazi \& Tchamba, 2019). Solving the soil fertility problem is the key to food security and to achieving a number of the sustainable development goals since agriculture is an economic motor that spurs development (Agyarko et al., 2011).

Agroforestry contributes to the increase and maintenance of soil fertility by providing litter and thus increasing the organic materials in the soil (Vitousek \& Sanford, 1986; Awazi \& Tchamba, 2019). It is established that physical conditions of soils, independent of nutrient content, can substantially affect fertility (Lal \& Greenland, 1979).

Studies examining the role of agroforestry in the improvement of soil fertility in crop lands is scarce in tropical Africa. It was therefore within this backdrop that this study sought to verify the role played by agroforestry in the improvement of soil fertility in Mbelenka - Lebialem, Southwest Cameroon.

\section{Materials and Methods}

\subsection{Description of the Study Site}

Mbelenka is found in Lebialem Division in the Southwest region of Cameroon. It is located at longitude $10^{\circ} 03^{\prime} \mathrm{E}$ and latitude $5^{\circ} 63^{\prime} \mathrm{N}$. Its vegetation is made up of mostly savanna type with xerophytic tree species that extends from M'muock-Fossimondi right up to the western flanks of the Bamboutus Mountain.

The Mbelenka area covers parts of Alou and Wabane sub-Divisions i.e, parts of Mmuock-Fossimondi, Mmuock-Leteh and Bamumbu Fondoms. It extends from the old market in M'muock-Fossimondi passing through the whole of M'muock-Leteh to Magha in the Bamumbu Fondom.

The area experiences two seasons; the dry season that begins in November and ends in April and the rainy season that commences in May and stretches up to October and early November with a mean annual rainfall of about $2000 \mathrm{~mm}$. It has an altitude of up to $2700 \mathrm{~m}$. Here the temperatures can go below $18{ }^{\circ} \mathrm{C}$ in the months of December to January but with a mean annual temperature of $18{ }^{\circ} \mathrm{C}$ (Wabane Council Report, 2013). It has a hilly and rolling landscape.

This area is located in the transition zone between the forest and the grassland and thus has characteristics of both zones but with the grassland savannah vegetation characteristics dominating. Due to the degradation of water catchments areas resulting from the felling of trees for farming and animal rearing activities, the water flow here has sharply decreased resulting in the scarcity of this resource.

\subsection{Materials}

The materials used for this study included: GPS to establish the exact location of each plot above sea level; Measuring tape to measure the size of the farm; Auger to take the soil samples; Plastic papers for soil sample collection; Core rings for bulk density measurements; Block note for field observations; Camera to take the photos of the various agroforestry systems as well as the location of the soil sampling sites where soils were collected; Materials for collection and description of soil samples; Questionnaires; and a soil laboratory to analyze 
the soil fertility status of the soils from the various systems.

\subsection{Methods}

\subsubsection{Sampling and Questionnaires Design}

The research was carried out in two Fondoms (M'muock-Fossimondi and M'Muock-Leteh). One hundred and twenty questionnaires were administered to 120 farmers ( 72 women and 48 men) chosen at random. The 120 farmers represented $10 \%$ of the population of the six villages in the two chiefdoms studied. Sixty questionnaires were administered in each of the chiefdoms.

Field surveys and observations were carried out to catalogue the various soil fertility determinants. This enabled the acquisition of firsthand information about the real nature of the soil fertility problems in the field. This also enabled the identification of the various types of agroforestry systems practiced in this area.

Semi-structured, closed and open-ended questionnaires were administered to 120 farmers chosen at random in the Mbelenka area to evaluate their perceptions, interventions on the declining soil fertility and impact of soil fertility decline. Questionnaires also enabled the acquisition of information about the yields from the various agroforestry systems.

The researcher together with the Sub-Divisional Delegate of Agriculture and Rural Development for Alou measured the outputs from the various agroforestry systems and these were compared to see the most productive system.

Participatory rural appraisal and rapid rural appraisal techniques were also applied on the target groups where group discussions gave a clue to some elements of fertility. Six group meetings were organized and 26 key informants were interviewed. These key informants were chosen based on their longevity in farm work. This also permitted the vivid understanding of the farmers' perceptions vis-à-vis the fertility of the soil of this area. Semi-structured and structured interviews were also conducted with key informants who were chosen based on their ages and longevity in farming activities. This permitted the acquisition of the various methods used by peasants in improving soil fertility as well as the yields from each agroforestry system.

\subsubsection{Soil Sampling and Analysis}

After walking round the Mbelenka area, bench marks (reference points) were established based on the geomorphology and altitude. Six quarters were identified based on altitude. In each quarter, four land areas of 2 hectares each were identified for data collection. These were; I (fallow land), II (cultivated farms with eucalyptus life fences), III (cultivated farms with cypress life fences), and IV (cultivated land with other tree species) with altitudes ranging from $2200 \mathrm{~m}$ to $2700 \mathrm{~m}$, respectively. Each land mapping unit was further subdivided into four sampling units and identified with numbers from 1-16. This was done in order to collect representative soil samples because soil samples should not be collected on large sampling units (more than 10 ha of land) (DAT, 2001).

From each sampling unit, 15-20 sub-samples were collected and combined into a composite sample representative of the area following the procedure below. At each sample collection point, a cut through the soil was made up to a depth of $30 \mathrm{~cm}$. A sample was then collected from this cut using a cutlass and a shovel. For each sampling unit, $15-20$ holes were dug with 
a shovel in a zigzag pattern, subsamples were collected to a depth of $30 \mathrm{~cm}$ extracted from each hole using a shovel and a cutlass. Sub-samples were then placed in a basin, mixed thoroughly and a one kg composite sample representative of the unit was taken out, placed in a transparent plastic paper and labelled with an indelible marker. Composite samples were air dried for 10 days and taken to the Soil and Plant Laboratory of the Faculty of Agronomy and Agricultural Science of the University of Dschang for analysis.

Once in the laboratory samples were crushed in a mortar of $30 \mathrm{~cm}$ diameter using a pestle of $10 \mathrm{~cm}$ long. The crushed samples were then passed through a sieve of $2 \mathrm{~mm}$ mesh. The particles left on the sieve (greater than $2 \mathrm{~mm}$ fraction) were used for coarse fraction determination; the particles that passed through the sieve (less than $2 \mathrm{~mm}$ fraction) were put into polyethylene bags, attributed laboratory codes, labelled with indelible markers and used for routine soil determination of physico - chemical properties like $\mathrm{pH}$, electrical conductivity, organic matter, exchangeable acidity, cation exchange capacity, total nitrogen, available phosphorus and exchangeable bases.

\subsection{Statistical Analysis}

Descriptive and inferential statistics were computed using the Statistical Package for Social Sciences (SPSS) 17.0. To determine the relationship between the various parameters observed and measured, correlation and regression statistical techniques were employed. A test for normality was carried out to check if the data gotten from the soil analysis is normally distributed at the different sites. Correlation analysis was carried out to verify whether yields and the various elements in soil samples are correlated. The Wilcoxon Mann-Whitney test was used to test whether there was a significant mean difference between the different soil fertility parameters and yield for the two major systems. Spearman correlation was used to check correlation between the different soil fertility parameters and yield since the results were not normally distributed.

\section{Results and Discussion}

\subsection{Characterisation of the Various Agroforestry Systems and Practices}

\subsubsection{Agroforestry Systems}

Three major agroforestry systems were characterised based on their structure, components and functions. These agroforestry systems had different arrangements, components and functions. This finding is similar to that of Nair (1985) and Young (1997).

\subsubsection{Agro-Sylvo-Pastoral Systems}

In this area, it was observed that agro-sylvo-pastoral systems existed where farmers keep their animals in paddocks and their excrements are transferred to farms for fertilization. Examples of animals kept in paddocks include: pigs, sheep, cows and goats. Among the farmers interviewed, $69.17 \%$ keep animals in paddocks, while $30.83 \%$ of the population does not keep animals. These farmers complained of lack of land for animals and also because animal rearing is a less lucrative business. Some farmers keep animals around their farm lands where their dung are used on farms, while others keep animals in paddocks but have shepherds that take them to far off grazing lands in the morning and bring them back in the evening. This system represented only $5 \%$ of the agroforestry systems identified. The components of this system included the following; cows, eucalyptus, Pear, cola nuts, sheep, 


\section{Macrothink}

Irish potatoes, carrots and cabbages.

\subsubsection{Agro-Sylvicultural Systems}

Cases of agro-sylvicultural systems were very rampant in the study area. Many farms in this area contained trees. Thus, scattered trees on farm lands were seen to be very prominent in this environment as $92.5 \%$ of the farms studied contained trees, while $7.5 \%$ lack trees in the farms. This $7.5 \%$ are small parcels within a life fenced area.

\subsubsection{Sylvo-Pastoral Systems}

The results of field surveys showed the sylvo-pastoral systems where farmers plant trees in life fenced areas for animals to graze on. The sylvo-pastoral system has greatly reduced as they have been converted into agricultural lands. Also, animals have been sent to distant hilly areas that have trees. It was observed that the trees in these distant areas are not usually cut because they serve for shade and food for the animals.

Trees are also allowed on lands reserved for animals. The sylvo-pastoral systems are also practiced in paddocks as well as around water sources where trees and animals go to drink. Most of these areas now are far off and hilly environments.

\subsubsection{Agroforestry Practices}

\subsubsection{Live Fences}

Life fences are very prominent in this area such that nearly all the farms and homes are surrounded by live fences. Some of these life fences serve as wind breaks and so protect houses from violent winds while some are used to protect crops from stray animals, demarcate farms, products such as wood and planks, and used to create paddocks for animals. The most dominant species used in life fences here is eucalyptus (Eucalyptus globulus).

\subsubsection{Scattered Trees on Farm Lands}

The act of allowing trees on farm lands has been a major practice by the peasants of this environment. They allow different species of trees on farm lands because of the numerous services and products they get from them.

The association of crops with trees is also observed particularly in the cases where farmers plant trees on their farm lands for the multiple functions the trees render them. Example of trees observed on the farm lands are Persia americana, cola nitida, other angiosperms and conifers.

\subsubsection{Slash and Burn}

Naturally growing leguminous trees species exist in this environment. These trees are colonizers and are often the first to grow in an abandoned land. After the fallow period most farmers usually cut them for firewood or apply the slash and burn system on them and the land is used for cultivation again.

\subsection{Soil Fertility Factors}

\subsubsection{Indicators of soil fertility decline}

The farmers of this area identify soil fertility decline using many indicators. These indicators usually help to forecast the yields of their crops. Table 1 below gives the various soil fertility decline indicators as identified by the peasants. 
Table 1. Distribution of farmers (\%) with respect to their perceptions of indicators of soil fertility decline

\begin{tabular}{lll}
\hline Indicator & Frequency & Percentage \\
\hline Rotten tubers & 120 & 100 \\
Wilting of stems & 120 & 100 \\
Yield decline & 120 & 100 \\
Much rain & 25 & 20.83 \\
Late sun & 14 & 11.67 \\
Arrival of clouds & 12 & 10.0 \\
Water erosion & 52 & 43.33 \\
Crop deficiency symptoms & 10 & 8.33 \\
Softening of soil & 7 & 5.8 \\
\hline
\end{tabular}

The farmers of this environment know the various soil fertility decline indicators. It was observed that soil erosion $(43.33 \%)$ is one of the most effective indicators of soil fertility decline as farmers complained of serious soil loss both during the rainy and dry seasons. Late sun is another indicator of fertility decline observed by farmers, this constitutes $11.67 \%$. Too much rain $(20.83 \%)$ is another indicator because it generally leads to leaching and erosion thus removing the soil nutrients. Elderly people of this area declared that the arrival of clouds in this area also causes a decline in soil fertility, which constitutes about $10.0 \%$ of the indicators. Crop deficiency symptoms $(8.33 \%)$ and softening of soils $(5.83 \%)$ are other indicators of fertility decline. This is in agreement with Hallie et al. (2006) that crops physiology and factors like rain and sun are used to check crop sensitivity to climate and soil fertility. Farmers complained that when crops grow, their physical appearance is always different from what is supposed to be. Also, the soils that used to be harder are gradually becoming too soft as farmers complained. One hundred percent of the farmers said rotten tubers, wilting of stems and yield decline are the main indicators of soil fertility decline in this area.

These indicators are in agreement with the findings of Odendo et al. (2009) in a study in Western Kenya that reported that $90 \%$ of peasants identified fertility decline using indicators such as yields, soil colour, presence of deficiency symptoms and weeds. The results are also in agreement with findings by Easterling (1996), Reilly and Schilmmelpfenning (1999) reported that yield decline and other factors are used to determine soil fertility decline and hence lead to the putting in place of adaptive measures.

\subsubsection{Soil Fertility Adaptation Methods (Strategies to Boost Output)}

Farmers overcome soil fertility decline by adapting to changes that fertility decline brings to them. These adaptation options permit farmers to continue farming despite the negative effects imputed on them by this decline. Table 2 below summarizes the various adaptation options taken by farmers. 


\section{Macrothink}

Table 2. Distribution of farmers (\%) with respect to soil fertility adaptation methods (peasant strategies to boost output)

\begin{tabular}{lll}
\hline Parameters and characteristics & Frequency (120) & Percentage \\
\hline Use of chemicals & 120 & 100 \\
Use of fowl droppings & 120 & 100 \\
Change of seeds & 120 & 100 \\
Erosion controlled farming & 120 & 100 \\
Seed preservation & 24 & 20.0 \\
Fallowing & 52 & 43.33 \\
Change of planting season & 41 & 15.83 \\
Increase farm sizes & 20 & 5.0 \\
Abandonment of use of herbicides & 5 & 4.17 \\
Use of green manure & 8 & 6.67 \\
Protection of boundary erosion & 6 & 5.0 \\
\hline
\end{tabular}

As a result of the soil fertility decline experienced by farmers, $43.33 \%$ of them used fallowing and $20 \%$ of them used seed preservation techniques as methods of assuring good output. Five percent of the farmers increased their farm sizes, while $15.83 \%$ of the farmers changed their planting season. This is in agreement with findings by Molua (2006) that farmers have to change their planting seasons to overcome climatic effects like rainfall and long periods of sunshine. About six point six-seven percent $(6.67 \%)$ of farmers used green manure, while $5 \%$ practiced the protection of boundary erosion. $4.17 \%$ of farmers abandoned the use of herbicides.

All the farmers indicated that the use of chemicals (fertilizers, insecticides, pesticides and fungicides), use of fowl droppings, erosion controlled farming and change of seeds as other local methods of soil fertility improvement.

The above results are in conformity with findings by Ndawa (2004) that erosion control, use of compost manure, improved fallowing and crop rotation are the various ways through which farmers adapt to declining output and soil fertility.

\subsubsection{Impact of Soil Fertility Decline on Farmers}

As farmers adapt to this fertility decline, the decline still has a negative impact on them. Table 3 below lists the impacts of fertility decline on farmers. 
Table 3. Distribution of farmers (\%) with respect to impact of soil fertility decline

\begin{tabular}{lll}
\hline Parameters and characteristics & Frequency(sample size: 120) & Percentage \\
\hline Unable to feed well & 120 & 100 \\
$\begin{array}{l}\text { Unable to pay children's fees and school } \\
\text { needs }\end{array}$ & 120 & 100 \\
Unable to pay hospital bills & 120 & 100 \\
Unable to settle family issues & 120 & 100 \\
Unable to continue planting & 30 & 25.0 \\
Unable to afford basic needs for the family & 59 & 49.17 \\
Unable to pay agricultural debts & 20 & 16.67 \\
Rural exodus & 11 & 9.17 \\
\hline
\end{tabular}

It was observed that $49.17 \%$ of the population is unable to afford basic needs for their families because of soil fertility decline. Twenty five percent of the population are unable to continue planting Irish potatoes, $16.67 \%$ of the population are unable to pay agricultural debts, while $9.17 \%$ of the population are moving to town or other areas to start a new life in a new environment.

One hundred percent of the farmers confirmed that soil fertility decline has caused them not to be able to feed well (poor feeding), pay children fees and school needs, pay hospital bills and also settle family issues.

\subsubsection{Factors That Contribute to Farmer'S Vulnerability}

Soil fertility decline alone does not make farmers vulnerable. Other factors are associated to soil fertility decline that make farmers vulnerable. Table 4 gives a list of other factors that coupled with soil fertility decline makes farmers vulnerable.

Table 4. Distribution of farmers (\%) with respect to factors that contribute to their vulnerability to soil fertility decline

\begin{tabular}{lll}
\hline Parameters & Frequency (120) & Percentage \\
\hline Bad roads & 120 & 100 \\
Poor seeds & 120 & 100 \\
High prices of inputs and low prices of outputs & 120 & 100 \\
Frequent diseases attack & 67 & 55.83 \\
Corruption of cooperatives leaders in sharing incentives & 36 & 33.0 \\
No financial institutions & 7 & 14.17 \\
\hline
\end{tabular}

It was observed that $55.83 \%$ of farmers are more vulnerable because of frequent disease 
attacks, $30.0 \%$ due to corruption in cooperatives and $14.17 \%$ because of lack of financial institutions. As a matter of fact, diseases like potato blight always cause farmers to spend much money and time fighting against these diseases with little success. This leads to increased losses. This is in agreement with observations by Damas and Israt (2004) that frequent diseases attack on crops and farmers makes crops more vulnerable and the farmers poor. Corruption in cooperatives limits farmers from having access to grants and subventions given by the government. Some farmers however are vulnerable because they lack financial institutions from where they can obtain loans for farming. High prices of inputs and low prices of outputs make farmers more vulnerable. This is in agreement with Hallie et al (2006) that low prices of outputs and high living standards coupled with high prices of inputs makes farmers to suffer.

All the farmers said that bad roads poor seeds, low prices of outputs and high prices of inputs increased their vulnerability.

\subsubsection{Factors Determining the Choice of Adaptation Options}

Farmers have many adaptation options they use to improve output. The choice of any of these options depends on a number of factors (Table 5).

Table 5. Distribution of farmers (\%) with respect to factors determining the choice of adaptation options

\begin{tabular}{lll}
\hline Parameters & Frequency & Percentage \\
\hline Quality of output & 56 & 46.67 \\
Nature of the stems of crops in each adaptation option & 28 & 23.33 \\
Family size & 23 & 19.17 \\
Trials of different methods & 13 & 10.83 \\
\hline
\end{tabular}

Many conditions are considered so that the option chosen will be well suited for the purpose. Farmers always consider the quality of output (46.7\%), nature of the stems of crops $(23.3 \%)$, family size $(19.2 \%)$ and often try and error methods $(10.8 \%)$ to determine their adaptation option. For example, if a farmer has a large family size, a suitable option will be to expand its farm land. A farmer who has not had any training will prefer to try all the adaptation options so as to see the option that best suits his/her situation.

3.2.6 Distribution of Farmers (\%) With Respect to Yields (Harvest) of Irish Potatoes (tons/ha)

Farmers have the potentials to get more yields per unit area. The fact that they have very low yields per unit area $(<1 \mathrm{t} / \mathrm{ha})$ then decreases their overall production.

Irish potato is the main crop in this area and all the farmers depend on it for survival because of its monetary and food values. Table 6 below shows the distribution of farmers with respect to the yields of this main crop Irish potato. 
Table 6. Distribution of farmers (\%) with respect to yields of Irish potatoes (tons/ha)

\begin{tabular}{lll}
\hline Parameters and characteristics & Frequency & Percentage \\
\hline$<1$ ton & 112 & 93.3 \\
$1-3$ ton & 7 & 5.8 \\
$>3$ ton & 1 & 0.8 \\
\hline
\end{tabular}

Overall, $93.3 \%$ of the population had a yield of less than 1 ton per hectare, $5.8 \%$ produce between 1-3 tons per hectare, while $0.8 \%$ of the population produced more than 3 tons per hectare. Though the soils of this area are naturally fertile, most of them have lost and are still losing their native fertility. Most farmers produce less than 1 ton/ha, which is far below the World's average of 15 tons/ha.

\subsection{Comparison Between the Two Major Agroforestry Practices Identified in the Study Area}

Since the slash and burn practice and the improved fallow were not prominent, the two main agroforestry practices identified in this area were life fences (AFP1) and scattered trees on farm lands (AFP2). This finding is different from the findings of Munjeb (2018), and Awazi et al (2019) who found a multitude of agroforestry practices on farmlands in north western Cameroon. Other studies undertaken by Nair (1989) and Nair (1993) found a multitude of agroforestry practices implemented by farmers across the tropics. Mechanical and chemical properties of the soils in the two systems is presented in Table 7, while Table 8 presents the summaries of the standard deviations and coefficient of variations of soil parameters and yields for the two agroforestry practices retained.

Table 7. Components of the soil in the two main agroforestry practices

\begin{tabular}{|c|c|c|c|c|c|c|c|c|c|c|c|c|c|c|}
\hline \multirow[t]{2}{*}{ System } & \multirow{2}{*}{$\begin{array}{l}\text { pH } \\
\text { water }\end{array}$} & \multirow[b]{2}{*}{ pHkcl } & \multirow[b]{2}{*}{$\mathbf{C} / \mathbf{N}$} & \multirow[b]{2}{*}{ OC } & \multirow[b]{2}{*}{$\mathbf{N}$} & \multirow{2}{*}{$\begin{array}{l}\mathbf{E x} . \\
\mathbf{A l}^{+++}\end{array}$} & \multirow[b]{2}{*}{$\mathbf{E C}$} & \multicolumn{5}{|c|}{ Exchangeable bases(Meq/100g soil) } & \multirow{2}{*}{ CEC } & \multirow{2}{*}{$\begin{array}{l}\text { Yields } \\
\text { (bags) }\end{array}$} \\
\hline & & & & & & & & $\mathbf{C a}$ & Mg & $\mathbf{K}$ & $\mathbf{N a}$ & Av. $\mathbf{P}$ & & \\
\hline AFP1 & 5.5 & 5.2 & 11.1 & 5.6 & 0.5 & 0.1 & 0.09 & 10.48 & 0.64 & 0.24 & 0.47 & 10.3 & 28.5 & 19.167 \\
\hline AFP1 & 5.5 & 5.3 & 12.9 & 5.2 & 0.4 & 0.2 & 0.05 & 8.64 & 1.2 & 0.24 & 0.47 & 1.8 & 20.2 & 10 \\
\hline AFP1 & 6.3 & 5.5 & 12.9 & 1.3 & 0.1 & 0.1 & 0.07 & 7.28 & 1.76 & 0.05 & 0.01 & 5.6 & 19.9 & 16.5 \\
\hline AFP1 & 4.3 & 4.2 & 10.4 & 3.4 & 0.3 & 8.7 & 0.06 & 9.2 & 3.04 & 0.05 & 0.01 & 9 & 26 & 18.57 \\
\hline AFP1 & 4.2 & 4.2 & 7.6 & 1.6 & 0.2 & 7 & 0.02 & 7.44 & 3.84 & 0.19 & 0.01 & 0.2 & 25.4 & 18.18 \\
\hline AFP1 & 4.1 & 4.2 & 5 & 0.5 & 0.1 & 8.5 & 0.03 & 8 & 2.4 & 0.19 & 0.01 & 10.5 & 18.2 & 20 \\
\hline AFP1 & 5.1 & 4.7 & 7.4 & 3.4 & 0.5 & 0.7 & 0.2 & 8.72 & 0.96 & 0.24 & 0.47 & 43 & 19.8 & 16.5 \\
\hline AFP1 & 5.1 & 4.8 & 9.6 & 5.4 & 0.6 & 0.9 & 0.05 & 6.24 & 0.48 & 0.05 & 0.01 & 9.9 & 18.3 & 18 \\
\hline AFP1 & 4.7 & 4.6 & 10.2 & 4.6 & 0.5 & 1 & 0.08 & 8.12 & 1.2 & 0.05 & 0.01 & 20.1 & 17.9 & 19 \\
\hline AFP2 & 5.4 & 4.6 & 8.2 & 3.2 & 0.4 & 1.7 & 0.09 & 7.04 & 0.56 & 0.24 & 0.47 & 19.9 & 15.3 & 18.33 \\
\hline AFP2 & 5.4 & 4.9 & 5.4 & 2.9 & 0.5 & 0.3 & 0.06 & 9.44 & 2.56 & 0.24 & 0.01 & 56 & 21.6 & 19 \\
\hline
\end{tabular}




\section{Ml Macrothink}

International Journal of Global Sustainability

ISSN 1937-7924

2019, Vol. 3, No. 1

\begin{tabular}{lllllllllllllll}
\hline AFP2 & 5.3 & 4.8 & 4.7 & 2.7 & 0.6 & 0.2 & 0.12 & 7.6 & 0.64 & 0.05 & 0.01 & 23 & 20.2 & 20 \\
AFP2 & 5.3 & 4.7 & 7.7 & 4.7 & 0.6 & 0.8 & 0.06 & 8.36 & 0.48 & 0.05 & 0.01 & 60.9 & 22.2 & 17 \\
AFP2 & 5.1 & 4.7 & 9.7 & 3.1 & 0.3 & 0.9 & 0.09 & 8.88 & 0.96 & 0.05 & 0.47 & 18.9 & 23.1 & 15.5 \\
AFP2 & 5.3 & 4.9 & 9 & 3.9 & 0.4 & 0.1 & 0.35 & 7.12 & 2.32 & 0.24 & 0.01 & 21.5 & 22.1 & 17 \\
AFP2 & 5.4 & 4.7 & 5.5 & 2.9 & 0.5 & 0.7 & 0.07 & 7.62 & 0.72 & 0.05 & 0.01 & 22.3 & 22.3 & 16.5 \\
AFP2 & 5.1 & 4.7 & 5.9 & 2.8 & 0.6 & 0.5 & 0.06 & 8.22 & 2 & 0.3 & 0.01 & 23.2 & 21.8 & 16 \\
AFP2 & 5.3 & 4.9 & 4.9 & 3.1 & 0.4 & 0.4 & 0.07 & 7.4 & 0.98 & 0.04 & 0.01 & 26.1 & 22.4 & 20.5 \\
average & $\mathbf{5 . 1 3}$ & $\mathbf{4 . 7 6}$ & $\mathbf{8 . 2 8}$ & $\mathbf{3 . 3 5}$ & $\mathbf{0 . 4 1}$ & $\mathbf{1 . 8 2}$ & $\mathbf{0 . 0 9}$ & $\mathbf{8 . 1}$ & $\mathbf{1 . 4 9}$ & $\mathbf{0 . 1 4}$ & $\mathbf{0 . 1 4}$ & $\mathbf{2 1 . 2 3}$ & $\mathbf{2 1 . 4}$ & $\mathbf{1 7 . 5 5}$ \\
\hline
\end{tabular}

Table 8. Summaries, standard deviation and coefficient of variation of soil fertility parameters and yield for the two major agroforestry practices

$\begin{array}{lllllll}\text { Mean Min } \quad \text { Max } & 1^{\text {st }} \text { Quart } & 3^{\text {rd }} \text { Quart } & \text { Sdtdev } & \text { C.V (\%) }\end{array}$

Parameter AFP1 AFP2 AFP1 AFP2 AFP1 AFP2 AFP1 AFP2 AFP1 AFP2 AFP1 AFP2 AFP1 AFP2

\begin{tabular}{|c|c|c|c|c|c|c|c|c|c|c|c|c|c|c|}
\hline $\mathrm{pH}$ & 5.0 & 5.3 & 4.1 & 5.2 & 6.3 & 5.4 & 4.3 & 5.3 & 5.5 & 5.4 & 0.73 & 0.12 & 14.61 & 2.20 \\
\hline OM (\%) & 5.94 & 5.58 & 0.90 & 4.70 & 9.70 & 8.10 & 2.70 & 4.90 & 8.90 & 5.50 & 3.30 & 1.12 & 55.53 & 20.12 \\
\hline $\begin{array}{l}\text { Total N } \\
(\mathrm{g} / \mathrm{kg})\end{array}$ & 0.036 & 0.048 & 0.010 & 0.030 & 0.060 & 0.060 & 0.020 & 0.040 & 0.050 & 0.060 & 0.019 & 0.011 & 52.83 & 22.87 \\
\hline $\mathrm{C} / \mathrm{N}$ & 10 & 7 & 5 & 5 & 13 & 10 & 8 & 5 & 11 & 8 & 2.62 & 1.89 & 27.09 & 27.85 \\
\hline $\begin{array}{l}\mathrm{K} \text { (méq } \\
100 \mathrm{~g} \text { ) }\end{array}$ & / 0.14 & 0.14 & 0.05 & 0.04 & 0.24 & 0.30 & 0.05 & 0.05 & 0.24 & 0.24 & 0.09 & 0.11 & 63.46 & 79.05 \\
\hline $\begin{array}{l}\text { Av P } \\
(\mathrm{mg} / \mathrm{kg})\end{array}$ & 12.27 & 30.2 & 0.20 & 18.90 & 43.00 & 60.90 & 5.60 & 21.50 & 10.5 & 26.10 & 12.8 & 16.19 & 95.20 & 53.62 \\
\hline $\begin{array}{l}\text { Yield ( } t \\
\text { ha) }\end{array}$ & 2.23 & 2.56 & 1.23 & 1.86 & 3.07 & 4.08 & 1.98 & 2.16 & 2.55 & 2.88 & 0.55 & 0.74 & 24.58 & 28.89 \\
\hline
\end{tabular}

Due to the fact that other types of agroforestry practices were not prominent, the two main agroforestry practices that were identified were life fences (AFP1) and scattered trees on farm lands (AFP2). The important elements of soil fertility such as $\mathrm{pH}$, organic matter, Total nitrogen, Potassium, available phosphorous and yields were compared between the two systems. It was observed that only phosphorous was significantly different in the two systems. It was however found that scattered trees on farm lands improve soil fertility more as evidenced by the higher yields/ton. This could be attributed to the diversity of tree/shrub species integrated by farmers on their farm plots when compared to live fences. Amongst these diverse species of trees/shrubs integrated on farmers' farm lands are different species of leguminous tree/shrub species that contribute to fix nitrogen, thereby improving soil fertility. This is the first study in Cameroon to produce such unprecedented findings, showing that scattered trees on croplands play a major role in improving soil fertility in south western 


\section{Macrothink}

Cameroon. Nevertheless, other studies have equally shown that agroforestry practices in general have the capacity to improve soil fertility (Young, 1997; Asaah et al., 2011; Leakey, 2017; Awazi \& Tchamba, 2018; Munjeb, 2018).

\subsubsection{Interpretation of the Various Soil Parameters}

\subsubsection{Appreciation of the Level of Soil Organic Matter}

Organic matter is either incorporated in the soil through the biomass of plants or through the supply of compost manure. Table 9 below gives information on the appreciation of organic matter, in the soil of the study area.

Table 9.Appreciation of the level of organic matter

\begin{tabular}{ll}
\hline Level & OM\% \\
\hline Very low & $<1,0$ \\
Low & $1,0-2,0$ \\
Average & $2,0-4,2$ \\
High & $4,2-6,0$ \\
Very high & $>6,0$ \\
\hline
\end{tabular}

Source: Adapted from Beernaert and Bitondo (1993).

Organic matter was found to have an average of 5.94 in AFP1 and 5.54 in AFP2 in the study site. The above results indicate that there is high organic matter in the study area. Between the two agroforestry practices, it was also observed that life fences have more organic matter than farm with trees. This is evident because there are mainly trees on the life fences compared to farmlands where both trees and shrubs are integrated.

\subsubsection{Appreciation of the Level of Soil Nitrogen}

Nitrogen is an essential element in crop nutrition. This is because it is found in chlorophyll, nucleic acids, and amino acids. It is a component of proteins and enzymes, which control almost all biological processes (Greg \& Hansen, 2005). Nitrogen is subject to more transformations than any other essential element. These cumulative gains, losses, and changes are collectively termed the nitrogen cycle. The ultimate source of $\mathrm{N}$ is $\mathrm{N}_{2}$ gas, which comprises approximately $78 \%$ of the earth's atmosphere. Inert $\mathrm{N}_{2}$ gas, however, is unavailable to plants and must be transformed by biological or industrial processes into forms which are plant-available. As a result, modern agriculture is heavily dependent on commercial $\mathrm{N}$ fertilizer (Greg \& Hansen, 2005). Table 10 below provides information for the appreciation of soil nitrogen in this area. 
Table 10. Appreciation of the level of nitrogen

\begin{tabular}{ll}
\hline Level & Ntot\% \\
\hline Very low & $<0,050$ \\
Low & $0,050-0,125$ \\
Average & $0,125-0,225$ \\
High & $0,225-0,300$ \\
Very high & $>0,300$ \\
\hline
\end{tabular}

Source: Adapted from Euroconsult (1989).

The results of soil analysis gave an average of 0.036 units nitrogen in AFP1 and 0.048 nitrogen in AFP2. This shows that nitrogen is very low in the soils of this environment. This explains why farmers talk of nutrient deficiency symptoms in crops. This nutrient deficiency symptoms are expressed through the yellowing of leaves and stems of crops (chlorosis) and also through the drying and dying of crops (Necrosis)

\subsubsection{Appreciation of the Level of Soil Available Phosphorous}

Another essential element for crops and plant growth is phosphorous. Phosphorous is concentrated in the seeds of many plants as phytin. According to Greg and Hansen (2005), it is important for plant development in several ways including: development of a healthy root system; normal seed development; uniform crop maturation; photosynthesis, respiration, cell division, and other processes; essential component of Adenosine Triphosphate (ATP), which is directly responsible for energy transfer reactions in the plant; essential component of DNA and RNA, and phospholipids, which play critical roles in cell membranes (Greg and Hansen, 2005).

Phosphorus solubility and plant availability are controlled by complex soil chemical reactions, which are often $\mathrm{pH}$-dependent. Plant availability of $\mathrm{P}$ is generally greatest in the $\mathrm{pH}$ range of 5.5 to 6.8. When soil $\mathrm{pH}$ falls below 5.8, $\mathrm{P}$ reacts with $\mathrm{Fe}$ and $\mathrm{Al}$ to produce insoluble $\mathrm{Fe}$ and $\mathrm{Al}$ phosphates that are not readily available for plant uptake. At high $\mathrm{pH}$ values, $\mathrm{P}$ reacts with $\mathrm{Ca}$ to form $\mathrm{Ca}$ phosphates that are relatively insoluble and have low availability to plants (Euroconsult, 1989). The $\mathrm{pH}$ of these soils fall within the range of phosphorous availability. This explains why a regression analysis showed that phosphorous significantly influences yields at 5\% significant level.

Table 11 below gives information for the appreciation of soil phosphorous

Table 11. Appreciation of the level of available phosphorous by the Bray2 method

\begin{tabular}{ll}
\hline Level & $\mathbf{P}(\mathbf{p p m})$ \\
\hline Very low & $<7$ \\
Low & $7-16$ \\
Average & $16-46$ \\
High & $>46$ \\
\hline
\end{tabular}

Source: Adapted from Euroconsult (1989). 


\section{Macrothink Institute ${ }^{\mathrm{TM}}$}

Results of the soil analysis gave an average of 12.27 ppm of phosphorous in AFP1 and 30.2 ppm in AFP2. This shows that phosphorous is low in AFP1 and high in AFP2. The average of the two systems gave $21.2 \mathrm{ppm}$ which falls in the average range. This makes phosphorous to be averagely available in the soils of this environment.

Although phosphorous is in these soils, it is not readily available to crops because these soils have low $\mathrm{pH}$ which makes phosphorous to be fixed by aluminum and iron, thus making phosphorous unavailable for crops. This is why a regression analysis shows phosphorous significantly influencing yields at 5\% significant level.

\subsubsection{Appreciation of the Level of Soil Cation Exchange Capacity (CEC)}

A soil's CEC should be considered when determining the appropriate rates and timing of nutrient applications in a fertilizer program. In general, smaller amounts of fertilizer, applied more often, are needed in low CEC soils to prevent leaching losses, while larger amounts may be applied less frequently in high CEC soils. For example, it may not be wise to apply K on very sandy soils with low CEC, especially in areas where rainfall is high. In comparison, on clayey soils with high CEC, adequate $\mathrm{K}$ can be applied in the rainy season for one or more future crops (Greg \& Hansen, 2005). Table 12 below gives a way for the appreciation of soil CEC.

Table 12. Appreciation of the CEC

\begin{tabular}{ll}
\hline Level & CEC (Meq/100g) \\
\hline Very high & $>40$ \\
High & $25-40$ \\
Average & $10-25$ \\
Low & $5-10$ \\
Very low & $<5$ \\
\hline
\end{tabular}

Source: Adapted from Beernaert and Bitondo (1993).

The average of soil CEC in the study area was $21.4 \mathrm{Meq} / 100 \mathrm{~g}$. Basing on Table 12 above, we can say that the soils of this environment have an average CEC. 'This explains why farmers of this environment have to constantly apply fertilizers for appropriate harvests.

This is because average cation exchange capacity does not permit a maximum holding of soil elements. Thus leaching of soil nutrients is common, making farmers to constantly apply chemical fertilizers. The average CEC values here indicates the higher amount of clay in the soil thus an average water holding capacity of these soils.

\subsubsection{Appreciation of the Level of Exchangeable Bases in the Soil}

Exchangeable bases are most present in soils with $\mathrm{pH}$ levels greater than 6.0. They are generally not available for plant uptake in acid soils since they may have been partially leached out of the soil profile (Greg \& Hansen, 2005). Table 13 below gives a clue to the appreciation of exchangeable bases in the soil. 
Table 13. Appreciation of the exchangeable bases in the soil

\begin{tabular}{lllll}
\hline Level & $\mathbf{C a}^{\mathbf{2 +}}$ & $\mathbf{M g}^{\mathbf{2 +}}$ & $\mathbf{K}^{+}$ & $\mathbf{N a}^{+}$ \\
\hline Very high & $>20,0$ & $>8,0$ & $>1,2$ & $>2,0$ \\
High & $10,0-20,0$ & $3,0-8,0$ & $0,6-1,2$ & $0,7-2,0$ \\
Average & $5,0-10,0$ & $1,5-3,0$ & $0,3-0,6$ & $0,3-0,7$ \\
Low & $2,0-5,0$ & $0,5-1,5$ & $0,1-0,3$ & $0,1-0,3$ \\
Very low & $<2,0$ & $<0,5$ & $<0,1$ & $<0,1$ \\
\hline
\end{tabular}

Source: Adapted from Beernaert and Bitondo (1993).

The results of soil analysis gave a $8.1,1.49,0.14$ and 0.14 for $\mathrm{Ca}, \mathrm{Mg}, \mathrm{K}$ and $\mathrm{Na}$ respectively. This shows that there is average Ca content in the soil, low $\mathrm{Mg}$ and $\mathrm{K}$ content in the soils of the study area. This is in agreement with Greg and Hansen (2005) because the soils of this area have $\mathrm{pH}$ values of less than 6 confirming their acidic nature.

Also, the average CEC of such soils would not allow the maximum retention of potassium and other exchangeable bases. This explains why farmers usually apply NPK fertilizers.

\subsubsection{Appreciation of the Level of Soil Acidity $(\mathrm{pH})$}

Many soil elements change forms as a result of chemical reactions in the soil. Plants may or may not be able to use elements in some of these forms. This is because $\mathrm{pH}$ influences the soil elements concentrations and, thus, the availability of plant nutrients, it is responsible for the solubility of many nutrient elements. Table 14 below permits the appreciation of soil $\mathrm{pH}$.

Table 14. Appreciation of soil acidity

\begin{tabular}{ll}
\hline Level & Value $\mathbf{( p H )}$ \\
\hline Very acidic & $<4$ \\
Acidic & $4-5,3$ \\
Averagely acidic & $5,3-6$ \\
Slightly acidic & $6-7$ \\
Slightly alkalinic & $7-8,5$ \\
Alkalinic & $>8,5$ \\
\hline
\end{tabular}

Source: Adapted from Beernaert and Bitondo (1993).

The results of soil analysis revealed that AFP1 has an average pH-water of 5.13 and AFP2 has an average $\mathrm{pH}$ of 4.76 . This gives an average $\mathrm{pH}$ of 4.95 . According to the interpretation Table 14 above, these soils are acidic.

Thus, the unavailability of some exchangeable bases is normal with such soils. This is because these nutrients are easily leached out. Acidic soils influence CEC and so the rate of retention of exchangeable bases is limited. An additional supply of such elements will boost fertility. This can be done through nitrogen fixing species and rapid growing species that provide biomass for the soil. This low $\mathrm{pH}$ also reduces phosphorous availability through fixation and inhibits nitrogen cycling (Yerima \& Van Ranst, 2005b). 
Table 15. Wilcoxon test parameters of different soil fertility parameters and yield for the two major agroforestry practices

\begin{tabular}{llllllll}
\hline Parameter & pH & OM & Total N & C / N & K & Av P & Yield \\
\hline W & 29 & 49 & 25.5 & 65 & 41.5 & 9 & 31.5 \\
P-value & 0.3251 & 0.4795 & 0.1905 & 0.0340 & 0.9624 & 0.0040 & 0.4527 \\
\hline
\end{tabular}

This test was used to verify the relationship between yields and the various soil parameters. The results showed that $\mathrm{pH}$, total Nitrogen and organic matter do not significantly influence yields in the two systems (Table 15). The only parameters that influence yields significantly in the two systems are the $\mathrm{C} / \mathrm{N}$ ratio and available phosphorous.

Immobilization and mineralization are ongoing processes in the soil and are generally in equilibrium with one another. This balance can be disrupted by the incorporation of organic residues that have high carbon to nitrogen ratios $(\mathrm{C}: \mathrm{N})$. The ratio of $\% \mathrm{C}$ to $\% \mathrm{~N}$, or the $\mathrm{C}: \mathrm{N}$ ratio, defines the relative quantities of these elements in residues and living tissues. Whether $\mathrm{N}$ is mineralized or immobilized depends on the $\mathrm{C}: \mathrm{N}$ ratio of the organic matter being decomposed by soil microorganisms (Greg \& Hansen, 2005).

The results are also in conformity with the work of Deshmukh (2012) that Phosphorus is the "master key to agriculture". This is because low crop production is more often due to lack of phosphorus than the deficiency of other elements except nitrogen. The importance of phosphorus in plant nutrition is can be seen in two dimensions: (1) it is essential for growth, cell division, root growth, fruit development and early ripening. It is also required for energy storage and transfer and (2) it is a constituent of several organic compounds including oils and amino acids.

From the importance of phosphorous above, a simple linear regression was made between the yields and available phosphorous. Table 16 below shows the simple linear regression between phosphorous and yields.

Table 16. Simple linear regression between yield and available P content

\begin{tabular}{lllll}
\hline & Estimate & Standard error & t value & Pr $(>\mathbf{l ~ t ~ l )}$ \\
\hline Intercept & 1.770444 & 0.167947 & 10.573 & $1.26 \times 10^{-8 * * *}$ \\
$\mathrm{P}$ & 0.029414 & 0.006233 & 4.719 & $0.000232 * * *$ \\
\hline
\end{tabular}

***, Significant at $1 \% \mathrm{p}$-level.

$\mathrm{R}^{2}=0.58 \quad \mathrm{p}-$ value $=0.0002318$

\section{The yield equation is:}

Yields $=1.77+0.03 P$

Where $\mathbf{P}=$ phosphorous

The above Table (16) gives a linear relationship between yields and soil phosphorous. It is observed that phosphorous explains about $58 \%$ yields with a P-value of 0.0002318 . This 
implies that it is highly significant.

The Spearman correlation (Table 17) was used to verify the relationship between yields and the soil parameters since the results were not normally distributed. It was observed that only available phosphorous significantly influences yields in this environment at 5\% significant level.

Table 17. Spearman test of correlation parameters of different soil fertility parameters and yield

\begin{tabular}{lllllll}
\hline Parameter & $\mathbf{p H}$ & $\mathbf{O M}$ & Total N & C / N & K & Av P \\
\hline $\mathrm{r}$ & -0.05 & 0.02 & $\mathbf{0 . 4 2 *}$ & -0.40 & 0.02 & $\mathbf{0 . 5 5} * *$ \\
P-value & 0.8545 & 0.9400 & $\mathbf{0 . 0 8 4}$ & 0.1012 & 0.9308 & $\mathbf{0 . 0 1 8 8}$ \\
\hline
\end{tabular}

$*$,**, Significant at $10 \%$ and $5 \%$ p-levels respectively.

From the analysis only two parameters were statistically significant. These included Total Nitrogen $(\mathrm{P}<0.10)$ and available phosphorous $(\mathrm{p}<0.05)$.

The above analysis indicates that the application of NPK fertilizer will influence yields significantly in this area.

\section{Conclusion and Recommendations}

Sustainable agriculture necessitates fertile soils. Soil fertility can be maintained and improved through agroforestry interventions. The main objective of this research work was to determine the agroforestry practice that best improves soil fertility as well as testing the hypothesis that "scattered trees on farm lands" best improve soil fertility in the study area. The results demonstrate that two main agroforestry practices exist in Mbelenka and include life fences and scattered trees on farm land. The statistical analysis using the Statistical package for social sciences (SPSS) showed that the only element that showed a significant difference in the two systems was available phosphorous observed more in scattered trees on farm land than in life fences. This confirmed the hypothesis that "scattered trees on crop lands" best improves soil fertility in the study area. A yield model was established indicating that yields are directly proportional to phosphorous in this environment.

Despite the fertility decline, farmers manage to adapt using their own methods such as change of planting season, change of seed preservation techniques, fallowing, abandoning the use of herbicides and protection of boundary erosion.

It was also discovered that farmers do not use only one factor to determine soil fertility decline but a combination of factors such as yields, nature of the crops, nature of tubers, erosion, softening of soils and crop deficiency symptoms. The choice of an agroforestry system and practices as well as the yield from each system had no relationship with sex, educational level and training. Soil fertility decline makes farmers to be unable to feed well, unable to sponsor their children in school, unable to settle family issues. Techniques for the restoration of the soils of this environment should depend on phosphorous. Following the model established, output will increase if the soil is supplied with more phosphorous. 


\section{Macrothink}

\section{Acknowledgements}

We are thankful to all the farmers whose farms were visited and to all the resource persons who provided valuable information needed for the study. We equally thank the Departments of Forestry and Soil Sciences of the University of Dschang, for providing vital morale, logistics and material support during and after the field surveys.

\section{Conflict of interest}

The authors declare that they have no conflicts of interest.

\section{References}

Agyarko, K., Asied, E. K., Atubiga, I. K., \& Anane, S. (2011). Determination and Restoration of Soil Fertility by Local Farmers: The Case of Techiman Municipality of Ghana.

Asaah, E. K., Tchoundjeu, Z., Leakey, R. R. B., Takousting, B., Njong, J., \& Edang, I. (2011) Trees, agroforestry and multifunctional agriculture in Cameroon. Int J Agric Sustain, 9, 110-119. https://doi.org/10.3763/ijas.2010.0553

Awazi, N. P., \& Tchamba, N. M. (2019). Enhancing agricultural sustainability and productivity under changing climate conditions through improved agroforestry practices in smallholder farming systems in sub-saharan africa. Afr. J. Agric Res, 14(7), 379-388. https://doi.org/10.5897/AJAR2018.12972

Awazi, N. P., Tchamba N. M., \& Temgoua, L. F. (2019). Enhancement of resilience to climate variability and change through agroforestry practices in smallholder farming systems in Cameroon. Agroforest Syst. https://doi.org/10.1007/s10457-019-00435-y

Beernaert, F., \& Bitondo, D. (1993). Land Evaluation Manual, part I and II. Department of Soil Sciences, University Centre of Dschang. Dschang, Cameroon.

Damas, P., \& Israt, R. M. (2004). Vulnerability and poverty: What are the causes and how are they related? Term Paper for Interdisciplinary course, International Doctoral Program at ZEF Bonn, November 2004.

DAT. (2001). Guide de fertilization des cultures (p. 34). Nouveau Brunswick, Canada.

Deshmukh, K. K. (2012). Evaluation of soilfertilitystatusfromsangamner area, ahmednagar district, maharashtra, India, sangamnernagarpalika arts, d.j.malpani commerce \&b.n. sarda science college, sangamner -422605 , dist. Ahmednagar, (M.S.), India.

Easterling, W. (1996). Adapting North American agriculture to climate change in review.Agric. Forest Meteorol, 80, 1-53. https://doi.org/10.1016/0168-1923(95)02315-1

Erisman, J. W., Galloway, J. N., Seitzinger, S. P., Bleeker, A., \& Butterbach-Bahl, K. (2011). Reactive nitrogen in the environment and its effect on climate change. Curr Opin Environ Sustain, 3, 281-290. https://doi.org/10.1016/j.cosust.2011.08.012

Euroconsult, (1989). Agricultural compendium for rural development in the tropics and subtropics (p. 740). Elsevier, Amsterdam.

Greg, M., \& Hansen, D. J. (2005). Basic soil fertility. Department of Crop and Soil Environmental Sciences, Virginia Tech.

Gruhn, P., Golleti, F., \& Yudelman, M. (2000). Integrated Nutrient Management, Soil Fertility and Sustainable Agriculture: Current Issues and Future Challenges. Washington D.C. International Food Policy Research Institute. Food, Agriculture and Environment Discussion 
Paper 32.

Hallie, E., Monica, W., Cristian, A., Gerardo, S. T., Luis, A., \& Bojórquez-Tapia. (2006). A Comparison of the Social Vulnerability ofGrain Farmers in Mexico and Argentina. AIACC Working Paper No. 29

Henao, J., \& Baanante, C. (2006). Agricultural production and soil nutrient mining in Africa: Implication for resource conservation and policy development. IFDC Tech. Bull. International Fertilizer Development Centre. Muscle Shoals, A1. USA.

Hossner, L. R., \& Juo, A. S. R. (1999). Soil Nutrient Management for Sustained Food Crop Production in Upland Farming Systems in the Tropics. Soil and Crop Sciences Department College Station Texas 77843, USA. Retrieved from http//www.agnet.org

Lal, R., \& Greenland, D. J. (1979). Soil physical properties and crop production in the tropics (p. 551). Chichester, UK,: John Wiley and Sons.

Leakey, R. R. B. (2017). Multifunctional agriculture: Achieving sustainable development in Africa (p. 459).

Marco, C. S. W., \& Maatman, A. (2006). Improving farming livelihoods in sub-Saharan Africa: the case for integrated soil fertility management.

Melane, K. Z., Pender, J., \& Köhlin, G. (2008). "Sustainable Agricultural Practices and Agricultural Productivity in Ethiopia: Does Agro-ecology Matter?" RFF Development Initiative Working Paper, Addis Ababa, Ethiopia.

Molua, E. L. (2002). Climate variability, vulnerability andeffectiveness of farm-level adaptation options: the challenges and implications for food security in Southwestern Cameroon. Department of Agricultural Economics, Georg-August University Goettingen, Platz der GoettingerS ieben 5, 37073 Goettingen Germany. Environment and Development Economics, 7, 529-545. https://doi.org/10.1017/S1355770X02000311

Munjeb, N. L., Yerima, B. P. K., \& Avana, T. M. L. (2018). Farmer's perception of soil and watershed degradation and the assessment of soil nutrients status under agroforestry systems in the Western Highlands of Cameroon: case of Ako sub-division. J Soil Sci Environ Manag, 9(8), 119-126. https://doi.org/10.5897/JSSEM2018.0684

Nair, P. K. R. (1985). Classification of agroforestry systems. Agroforestry Systems, 3(2), 97-128. https://doi.org/10.1007/BF00122638

Nair, P. K. R. (1989). Agroforestry Systems in the tropics. Dordrecht, Netherlands: Kluwer Academic Publishers.

Nair, P. K. R. (1993). An introduction to agroforestry. Dordrecht, Netherlands: Kluwer Academic Publishers.

Ndawa C. G. (2004). Factors affecting smallholder farmers' adoption of soil and water conservation practices in Zambia. A Thesis Submitted to Michigan State University in partial fulfillment of the requirements for the degree of MASTER OF SCIENCE Department of Agricultural Economics.

Odendo, M., Obare, G., \& Salasya, B. (2009). Farmers' Perceptions and Knowledge of Soil Fertility Degradation in two contrasting sites in Western Kenya. Kenya Agricultural Research Institute (KARI), Socio-economics Division, P.O. Box 169, Kakamega, Kenya Department of 


\section{Macrothink}

International Journal of Global Sustainability

ISSN 1937-7924 2019, Vol. 3, No. 1

Agricultural Economics and Business Management, Egerton University, P.O. Box 536, Njoro, KenyaFood Security Center, University of Hohenheim, 70599 Stuttgart, Germany

Reilly, J. M., \& Schilmmelpfenning, D. (1999).Agricultural impact assessment,vulnerability and the scope for adaptation. Climatic Change, 43, 745-788. https://doi.org/10.1023/A: 1005553518621

Sanchez, P. A., \& Salinas, J. (1981). Low input technology for managing oxisols and utisols in Tropical America. https://doi.org/10.1016/S0065-2113(08)60889-5

Sanchez, P. A., Shepherd, K. D., Soule, M. J., Place, F. M., Buresh, R. J., Izac A-MI, ... Woomer, P. L. (1997). Soil fertility replenishment in Africa. An Investment in natural resource capital. In Replenishing Soil Fertility in Africa, Buresh RJ, SanchezPA, Calhoun F (eds). Soil Science Society of America: Madison, WI.

Vitousek, P. M., \& Sanford Jr, R. L. (1986). Nutrient cycling in moist tropical forest. Annual Review of Ecology and Systematics, 17, 137-167. https://doi.org/10.1146/annurev.ecolsys. 17.1.137

Wabane Council Report. (2010). National Community Driven Development Program: Consolidated Participatory Diagnosis Report for Wabane.

Wabane Council Report. (2013). National Community Driven Development Program: Communal development plan Wabane.

Yerima, B. P. K., \& Van Ranst, E. (2005) Major soil classification systems used in the tropics: soils of Cameroon. Trafford publishing, 6E-2333 Government st., Victoria, BC Canada.

Young, A. (1997). Agroforestry for soil management, Nairobi: ICRAF, Cab International.

\section{Copyright Disclaimer}

Copyright for this article is retained by the author(s), with first publication rights granted to the journal.

This is an open-access article distributed under the terms and conditions of the Creative Commons Attribution license (http://creativecommons.org/licenses/by/3.0/). 